\title{
BEJING : MAKELAR SUARA PILKADES
}

\author{
Asmawati \\ Universitas Brawijaya Malang \\ email : asmawatisuwarno@gmail.com
}

\footnotetext{
Paper Accepted: 17 September 2021 Paper Reviewed: $18-23$ September 2021 Paper Edited: 24 September-04 Oktober 2021 Paper Approved: 05 Oktober 2021
}

\begin{abstract}
ABSTRAK
Penelitian ini bertujuan untuk mengungkap bagaimana Bejing sebagai tokoh lokal yang memiliki status sosial yang tinggi di masyarakat bertindak sebagai makelar suara dalam proses pemilihan klebun (kepala desa). Penelitian ini menggunakan jenis penelitian kualitatif dengan metode studi kasus yang dapat memberikan nilai tambah pada pengetahuan secara unik terkait makelar suara yang diperankan oleh tokoh lokal. Berdasarkan wawancara mendalam dan observasi di lapangan peneliti menemukan bahwa praktek makelar suara banyak dilakukan oleh tokoh non politik yang memiliki pengaruh. Hubungan timbal balik menjadi faktor utama kegiatan pemakelaran suara. Kontribusi keilmuan artikel ini adalah menjelaskan bagamana praktek makelar suara dalam proses pemilihan klebun.
\end{abstract}

Kata Kunci : Bejing, Makelar Suara, Klientelisme, Pilkades

\section{PENDAHULUAN}

Pertukararan materi baik berupa barang, uang dan bantuan untuk pemilih menjadi lazim dilakukan oleh negara demokrasi berkembang. Salah satunya Indonesia, strategi pemilihan tidak lepas dari praktek-praktek yang melibatkan dua pihak untuk melakukan transaksi pembelian suara. Hal ini lazim dilakukan ketika dua belah pihak sama-sama memiliki kepentingan. Dengan kata lain hubungan timbal balik inilah menjadi awal praktek pembelian suara menjadi normal dilakukan.

Secara ilmiah, broker atau lebih dikenal dengan sebutan makelar suara di Indonesia memiliki peran sebagai mobilisasi massa dalam pemilu. Makelar suara menjadi aktor utama yang memiliki peran penting dalam kemenangan kandidat. Hal ini diperkuat oleh studi dari seluluh dunia yang menjelaskan bagaimana efektifitas broker dalam bekerja. Keberadaan broker dimanfaatkan oleh calon kandidat mengingat mereka mampu mengenali calon pemilih dengan baik (Ravanilla et al., 2017). Broker juga mampu bertugas mempengaruhi pemilih agar memilih calon kandidat yang sedang diusung (Tawakkal, 2017). Broker juga mampu bekerja dengan baik dan memiliki pengalaman panjang terhadap para pemilih akar rumput (Rodrigo Zarazaga, 2014). Temuan-temuan inilah yang menjelaskan bagaimana keberadaan broker sangat efektif dalam mencari suara pemilih.

Broker yang bertindak sebagai makelar suara yang menghubungkan kandidat dan pemilh harus memiliki cara khusus agar dirinya mampu 
diperhitungkan oleh kandidat yang akan menyewa jasanya. Hal ini ditunjuukkan engan seberapa besar pengaruhnya didalam sebuah komunitas. pengaruh yang dimiliki broker inilah yang akan menjadi jalan awal bagi keyakinan kandidat menyewa jasanya dalam memobilisasi pemilih. dengan demikian, Boker harus selalu memperhatikan segala hal terkait reputasi dan nama besarnya untuk dikenal di seluruh kalangan.

Terlepas dari pengaruh dari broker, hubungan timbal balik menjadi salah satu cara yang dapat ditempuh broker dalam memetakkan suara pemilih pasti. Rasa balas budi menjadi satu mekanisme yang mampu menekan pemilih untuk memberikan loyalitasnya kepada kandidat mengingat beberapa manfaat yang telah di dapat dari transaksi timbal balik tersebut. Ketika pemilih melakukan penghianatan maka dia akan dihadapkan pada situasi dimana kesenangan dan manfaat ketika kandidat yang di dukungnya tidak mendapatkan kemenangan.

Bejing sebagai tokoh lokal di Madura memiliki peran penting dalam proses mobilisasi massa. Keberadaanya selalu dimanfaatkan oleh tokoh politik yang ingin menduduki pemerintahan formal. Hal ini dilatar belakangi oleh pengaruh yang dimiliki Bejing sangat besar. Bejing mampu menggerakkan pemilih akar rumput untuk mendukung bos politik mereka. Bejing juga mampu mengenali preferensi pemilih dengan baik mengingat Bejing hidup dalam keseharian berdampingan dengan masyarakat (Asmawati et al., 2020). Inilah yang menjadi alasan kuat para kandidat memanfaatkan aktor non-politik dalam proses mobilisasi massa (Komito, 1992)

Telah banyak penelitian terdahulu yang menjelaskan terkait bagaimana makelar suara melakukan peranya dalam proses pemilihan. Pertama, Penelitian (Aspinall, 2014) yang menjelaskan terkait perilaku makelar suara di Indonesia yang melakukan penghianatan dengan alasan imbalan finansial. (Towar et al., 2017) menjelaskan terkait loyalitas makelar suara yang dilatarbelakangi oleh status sosial dan reputasi. (Nichter \& Palmer-Rubin, 2014) menjelaskan bagaimana praktek klientelisme di Mexico yang melibatkan jual beli suara. (Mattlin, 2004) dalam menjelaskan peelitianya di Taiwan bahwa ada kelompok informal yang berperan sebagai makelar suara dengan membentuk piramida bersarang. Beberapa literature di atas menjelaksan bagaimana keberadaan tokoh informal menjalankan peranya sebagai makelar suara membantu kandidat dalam memenangkan kontestasi politik.

Penelitian (Aspinall, 2014) terbatas pada pembahasan terkait bagaimana perilaku penghianatan yang dilakukan oleh broker kepada kandidat ketika kandidat mengalami kekurangan sumber daya. Aspinall belum membahas terkait hubungan kandidat dengan broker yang bekerjasama untuk kemenangan kandidat. ketika kandidat mengalami kekalahan sumber daya maka broker akan cenderung istirahat bersih atau membelot ke kandidat lawan.

Penelitian (Towar et al., 2017) menjelaskan bagaimana perilaku loyalitas broker kepada kandidat dimana broker akan mempertahankan kesetiaanya berdasarkan mekanisme reputasi sosial. Penelitian ini terbatas pada perilaku broker dengan kandidat, lebih jauh penelitian ini belum membahas bagaimana kandidat, pemilih dan broker harus bekerjasama untuk mendapatkan kemenangan.

Penelitian (Nichter \& Palmer-Rubin, 2014) menjelaskan bagaimana klientelisme berkembang baik di Mexico. Hal ini terkait hubungan penting yang tidak pernah tersentuh perhatian oleh literature lain dimana pemilih dan mesin politik bekerjasama untuk kemenangan. Namun penelitian ini terbatas pada kandidat yang belum tersentuh.

Penelitian (Mattlin, 2004) mnjelaskan bahwa ada struktur piramidal bersarang dari tokoh informal dalam kemenangan pemilihan. Treuktur politik informal ini ditambah dengan loyalitas partai yang lemah. Penelitian ini menjelaskan kepentingan hubungan untuk menuju politik yang lebih luas.

Analisis artikel ini terfokus pada Bejing di Pamekasan Madura yang menjalankan peranya sebagai makelar suara. Asumsi penting dalam pembahasan 
terkait broker (makelar suara) adalah mereka bekerja dengan baik terhadap bos politik mereka. Meski pada prakteknya masih ditemukan broker yang malas dan tidak loyal (Aspinall, 2014) namun tetap saja asumsi dari penelitian tersebut menjelaskan bahwa broker cukup efektif untuk diandalkan dalam perekrutan suara.

Menggunakan data dari Pamekasan Madura dengan menyatukan informasi terperinci tentang Bejing yang berperan sebagai makelar suara, penelitian ini memberikan bukti bahwa Bejing dengan status sosial yang dimiliki mampu memiliki power dalam menarik pemilih untuk memberikan loyalitasnya.

Praktek klientelisme yang diperankan oleh Bejing kepada calon pemilih juga tidak terbatas pada pertukaran materi, lebih dari itu Bejing menawarkan imbalan jangka panjang untuk para pemilih yaitu rasa aman di lingkungan tempat tinggalnya sebagai satu kelebihan Bejing dalam memanfaatkan powernya di lingkungan masyarakat.

\section{METODE PENELITIAN}

Artikel ini menggunakan jenis penelitian kualitatif dengan metode studi kasus dimana peneliti ingin menetahui secara mendalam terkait fenomena makelar suara yang diperankan oleh Bej̈ng. Wawancara mendalam dilakukan kepada 4 Bejing yang bertindak sebagai broker dimana pertanyaan-pertanyaan yang diajukan mengenai kerangka kerja Bejing dalam bertindak sebagai makelar suara dalam menargetkan loyalitas pemilih. Observasi dilapangan juga dilakukan sebagai penguat data. Peneliti juga melakukan wawancara non formal terhadap masyarakat yang bertindak sebagai pemilih guna menambah informasi. Tidak hanya itu, wawancara informal juga melibatkan calon klebun yang bertindak sebagai orang yang menggunakan jasa Bejing.

Penyusunan artikel terbagi kedalam beberapa pembahasan. Pertama, menjelaskan terkait power Bejing yang bertindak sebagai makelar suara. Bagian ini menjelaskan bagaimana Bejing sebagai tokoh lokal diperhitungkan keberadaanya dalam proses mobilisasi massa pilkades.

Kedua, praktek klientelisme yang dilakukan oleh Bejing dimana Bejing tidak hanya menawarkan uang sebagai salah satu alat untuk melakukan hubungan timbal balik. Lebih dari pada itu, Bejing menawarkan apa yang dibutuhkan oleh pemilih jangka panjang.

Ketiga, pembentukan jejaring sosial Bejing dan pendistribusian barang dimana dalam hal ini menjelaskan kegiatan Bejing sebagai makelar suara. Artikel ini diakhiri dengan penyimpulan argumen mengenai kegiatan Bejing sebagai makelar suara.

\section{Pembahasan}

\section{Power Bejing Sebagai Makelar Suara}

Demokrasi desa memiliki perjalanan panjang dimana saat ini pemilu pilkades memiliki format yang berbeda dari pemilihan lainya (Tawakkal, 2017). Hal ini dibuktikan dengan tidak adanya keterlibatan formal dari partai politik yang menaungi kandidat. fakta ini memaksa kandidat mencari mesin politik secara mandiri yang dapat diandalkan dalam proses memobilisasi massa. Dengan demkian kandidat harus memperhitungkan keberadaan orangorang yang mampu bekerja secara efektif untuk kemenanganya menuju kancah politik formal.

Kontestasi pilkades menjadi satu ajang dimana para calon klebun akan berlomba-lomba untuk memenangkan kontestasi dan merebut loyalitas pemilih. hal penting yang harus diperhatikan calon klebun adalah dengan mencari orangorang yang dapat dimanfaatkan untuk memperoleh kemenangan. Kesalahan calon klebun dalam memilih orang-orang yang akan dipekerjakan sebagai mesin mobilisasi massa akan berakibat pada hasil akhir yang akan didapatkan. Dengan kata lain, kemenangan klebun ditentukan seberapa pintar calon klebun mencari orang-orang berpengaruh yang dapat menarik dukungan masyarakat.

Kabupaten Pamekasan dikenal dengan keberadaan Bejing sebagai tokoh lokal yang memiliki kedudukan tinggi. Status sosial yang dimiliki Bejing 
menempatkan Bejing sebagai salah satu tokoh lokal yang diperhitungkan keberadaanya. bermodalkan kharisma dan kewibawaan yang dimiliki menjadikan Bejing disegani oleh banyak masyarakat. oleh sebab itu, keberadaan Bejing banyak diperhitungkan oleh kandidat-kandidat yang akan mencalonkan diri menjadi klebun dalam mempengaruhi pemilih untuk memberikan loyalitasnya demi sebuah kemenangan. Bahkan, pengaruh Bejing inilah yang menjadikan banyak Bejing terjun menjadi klebun di desanya. Tidak heran jika banyak klebun yang memiliki trah sebagai Bejing (Ainillah, 2016).

Keberadaan Bejing sebagai makelar suara dilatar belakangi oleh pengaruhnya yang besar untuk mempengaruhi pemilih. hal ini dipengaruhi oleh kewibawaan yang dimiliki oleh Bejing. Status sosial yang tersemat dalam trah Bejing menunjukkan bagaimana posisinya menjadi salah satu tokoh berpengaruh yang akan didengarkan oleh masyarakat. sebenarnya, di Kabupaten Pamekasan Madura memiliki tokoh lokal yang lebih berpengaruh dari Bejing yaitu Kyai dimana posisi kyai menjadi nomor satu. Namun, untuk urusan Pilkades, Bejing menjadi satu-satunya tokoh lokal yang memiliki pengaruh dan andil besar (Asmawati et al., 2021). Kewibawaan yang dapat memberikan pengaruh besar untuk menarik pemilih dimanfaatkan oleh kandidat untuk mencari loyalitas pemilih.

Kewibawaan Bejing didapat bukan semata datang dengan mudah. Bejing mempertahankan status sosial nya dengan cara memenangkan kontestasi pemilihan klebun. Ketika Bejing menang, maka pengaruhnya akan naik dengan sendirinya. Begitu pula sebaliknya, ketika Bejing kalah maka Bejing akan mendapatkan kenyataan bahwa pengaruhnya akan sedikit berkurang. Faktor ini menjadi pertimbangan kandidat untuk merekrut Bejing mana yang dapat diandalkan untuk mendapatkan kemenangan.

Bejing sebagai tokoh lokal juga dikenal dengan Jagoanisme yang melekat. Bejing dengan khas intimidasi dan kemerasan yang dilakukan dalam penyelesaian sebuah masalah menjadi khas dimana keberadaanya ditakuti oleh masyarakat. Adagium "etembheng pote mata ango" poteah tolang (daripada menaban malu lebih baik bilang nyawa saja)" menjadi khas dimana Bejing akan mempertaruhkan nyawa nya demi sebuah harga diri Khatib 2016 dalam (Asmawati et al., 2020). Hal ini dibuktikan dengan ungkapan Agus selaku Bejing menyatakan bahwa :

"Ango'an ka elangah nyabeh
katembeng kaelangan harga diri.
Dedih mon bedeh masalah se
bubunganah kalaben hara diri
biasanah cara ka angguy mareh pas
osa kalaben carok. Bejing tak in
mainan mon masalah harga diri."
Pilkades 2019
"Mending kehilangan nyawa dari pada
harga diri yang bilang. Jadi, kalau ada
masalah yang menyangkut perebutan
harga diri biasanya penyelesaian selalu
dengan carok. Bejing tidak pernag
main-main untuk urusan harga diri."
Pilkades 2019

Orang Madura yang memilih tindakan kekerasan berupa carok dalam penyelesaian sebuah masalah dianggap sebagai orang yang mampu membela dan mempertahankan harga dirinya. Hal ini akan dinilai dan dipandang masyarakat sebagai seorang Bejing (Rozaky Abdur, 2004).

Jagoanisme yang dimiliki Bejing juga menjadi daya tarik bagi kandidat untuk menarik loyalitas pemilih. kandidat menilai bahwa inilah yang menjadi faktor yang mampu menarik masyarakat untuk patuh terhadap arahan yang diberikan oleh Bejing. Dengan demikian suara masyarakat bisa terjaga dengan alasan ketakutanya kepada intimidasi yang diberikan oleh Bejing.

Bejing sebagai makelar suara juga memiliki kemampuan untuk mengenal situasi di lingkunganya. Hal ini dibuktikan dengan pembacaan Bejing terhadap sitiasi lingkungan masyarakat sangat tajam dan tepat (Hannan et al., 2018). Beberapa alasan Bejing mampu mengenal lingkungan hingga preferensi pemilih dari setiap indvidu adalah Bejing hidup dalam lingkungan masyarakat akar rumput. 
Keberadaan Bejing yang melakukan kegiatan sehari-hari dengan masyarakat yaitu ngopi di warung kopi, bercengkrama dengan banyak masyarakat menjadikan Bejing tahu apa yang sedang terjadi di masyarakat. Dengan demikian Bejing sangat mudah mengetahui masyarakat mana yang akan melabuhkan suaranya kepada kandidat yang sedang mereka usung.

\section{Klientelisme Bejing}

(Robinson \& Verdier, 2013) menjelaskan pemilu seharusnya tidak ada praktek pembelian suara. karena pemungutan suara bersifat rahasia maka suara pemilih tidak dapat diobservasi dan janji pemimpin tidak dapat dilaksanakan. Dengan latar belakang permasalahan di atas maka tidak ada cara formal yang dapat mengontrak suara pemilih. dengan demikian hubungan timbal balik menjadi salah satu cara agar pemilih dapat memberikan loyalitasnya kepada kandidat.

Sebagai makelar suara, Bejing dituntut agar mengenali pemilih dan mengantongi suara pemilih dengan pasti. Tidak ada yang mampu menebak sejauh mana loyalitas pemilih ketika di bilik pemungutan suara. pemilih bisa dengan mudah mengantongi tawaran yang diberikan namun memilih sesuai hati nurani di balik bilik pemungutan suara. Fenomena ini tentu menjadi hal yang harus diperhatikan secara khusus bagi Bejing. Dengan demikian banyak hal yang harus dilakukan untuk memastikan suara pemilih. hal inilah yang menjadi acuan didapatkanya loyalitas pemilih.

Pertama, hubungan timbal balik dilakukan oleh Bejing dengan pemilih. hubungan timbal balik ini mampu diyakini sebagai mekanisme yang dapat menjadikan pemilih memberikan loyalitasnya dengan alasan beban dan tanggung jawab dari sebuah kesepakatan. Timbal balik antara pemilih dengan broker juga menjadi alasan yang dapat mempertahankan pembelian suara (Inan \& Chechter, 2012). Hubungan timbal balik selalu diyakini sebagai kontrak yang mengikat pemilih didalam fenomena pemungutan suara yang rahasia. Salah satu contoh adalah fenomena pemberian bir di
China kepada pemilih ketika akan melakukan pemungutan suara (Kennedy, 2010).

Sebagai makelar suara tentu Bejing dituntut untuk mengidentifikasikan apa yang pemilih butuhkan. Tidak semua pembelian suara harus dilakukan dengan pertukaran uang. Hal tersebut menjadi alasan bahwa pertukaran uang akan membutuhkan cost yang sangat besar (Mahsun, 2020). Dengan demikian broker bertugas untuk memberikan apa yang dibutuhkan oleh pemilih. ketika pemilih sedang sakit, maka yang dibutuhkan adalah obat bukan beras (Aspinall, 2014).

Pertukaran uang yang dilakukan oleh Bejing diberikan kepada para calon pemilih. hal ini menjadi hal yang lumrah dilakukan mengingat tradisi yang dilarang namun tidak di tentang. Pemilih akan menanyakan uang yang diperuntukkan untuk suara mereka. Istilah yang sering muncul yaitu "Tongket (Setong Seket)" ini berarti bahwa satu suara yang diberikan harus ditukar dengan uang lima puluh ribu. Ada lagi istilah "Berseb (Beras So Pesse)" ini berarti bahwa pertukaran suara harus diberikan beras beserta uang.

Diluar dari pertukaran uang, hubungan klientelisme yang dilakukan oleh Bejing terhadap pemilih dilakukan dengan penawaran jangka panjang dimana Bejing sebagai tokoh yang dikenal dengan jagoanisme menawarkan keamanan bagi pemilih. Pemilih akan memperhitungkan hal tersebut dimana keamanan harta benda dan ternak juga menjadi hal penting. Bejing sebagai jagoanisme tentu kenal dengan perampok dan preman dimana-mana. Dengan adanya jaminan keamanan yang diberikan oleh Bejing maka wilayah mereka tidak akan dimasuki oleh para perampok. Hal inilah yang menjadikan Bejing mampu mengantongi suara pemilih dengan pasti. Ketika para pemilih berkhianat maka hal sebaliknya akan terjadi dimana daerah meraka akan tidak aman. Akan banyak masyarakat yang kehilangan harta benda dan ternak mereka ketika mereka memilih untuk berkhianat.

Klientelisme yang terjadi antara Bejing dan pemilih dilatarbelakangi oleh hubungan dekat diantara mereka. Kasus ini menjelaskan bagaimana Bejing hidup 
bertetangga dengan pemilih. atas dasar inilah Bejing menjadi sosok handal dalam mengetahui apa yang menjadi daya tarik pemilih untuk dapat memberikan loyalitasnya. kepentingan pemilih dan Bejing selaras dimana hal ini menjadi syarat hubungan klientelisme dapat berjalan dengan baik. Bejing membutuhkan uang dari kandidat sekaligus status sosial yang tinggi dimata masyarakat ketika Bejing dapat memenangkan kontestasi. Sedangkan masyarakat butuh sosok Bejing untuk memenuhi kebutuhan mereka dimana dalam hal ini baik kebutuhan yang berjangka pendek (uang tunai, beras dan materi lainya) atau kebutuhan berjangka panjang (keamanan, perlindungan dan pembangunan). Masyarakat meyakini bahwa Bejing adalah salah satu sosok yang mampu memenuhi kebutuhan mereka. Tentunya, dengan pertukaran kepentingan inilah yang mampu mewujudkan masingmasing dari apa yang mereka butuhkan.

Faktor penting lainya yang melatarbelakangi hubungan klientelisme antar Bejing dan pemilih adalah kemenangan Bejing sebagai makelar suara akan mengerti apa saja yang dibutuhkan oleh pemilh. Ketika Bejing kalah dari Bejing lawan maka pemilih akan menemukan pemimpin Bejing baru yang belum tentu menawarkan hal-hal yang mereka butuhkan. Peneliti mengamati langsung bagaiman Bejing memberikan makanan dan uang kepada pemilih dengan memberikan sedikit ancaman kepada pemilih dengan mengatakan bahwa :

\section{"mon sengkok so be'en tak menang kaade en sengkok so be en tak kerah olle kakanan bik, pesse pole. Deggik se menang bisa beih atindak sanyamanah ka sengkok so be en reah koduh menang pas be ien tak olle abianat ka sengkok"pilkades 2019}

yang secara kasar dapat diartikan sebagai berikut :

\footnotetext{
"ketika kita tidak menang maka belum tentu kedepanya akan dapat makanan dan uang lagi. Babkan bisa saja yang menang akan bertindak. semannya kepada kita. Jadi,
}

bagaimanapun kita harus menang dan kamu tidak boleh berkbianat." Pilkades tabun 2019

Kesimpulanya, pemiih tahu bahwa ketika broker tidak bekerja dengan baik maka akan digantikan oleh broker yang baru. Hal ini akan dialami ketika Bejing tidak dapat memenangkan kontestasi maka Bejing lain yang akan mengambil alih kuasa. Jika hal itu terjadi, pemilih tidak akan pernah tahu seberapa banyak hal-hal baik dan menguntungkan yang akan mereka dapatkan dari broker baru.

Tidak hanya terbatas pada hubungan timbal balik antara pemilih dan makelar suara, Bejing juga melakukan hubungan timbal balik kepada kandidat. hal utama yang perlu digaris bawahi bukan terbatas hanya pada keuntungan materi. Lebih dari pada itu, Bejing memastikan bahwa adanya hubungan timbal balik antara Bejing dan kandidat akan mampu menguntungkan pemilih mereka. Beberapa hal yang dapat dijabarkan dalam hal ini diantaranya adalah :

Pertama, Bejing memastikan bahwa hubungan dengan pemilih akan selalu dijaga dengan baik. Cara yang dapat ditempuh adalah dengan memberikan ketepatan janji yang sudah ditawarkan oleh kandidat. Bejing dalam hal ini memantau kandidat untuk menepati janji yang sudah diberikan kepada pemilih. Dengan demikian pemilih akan semakin yakin bahwa Bejing yang sedang menjalin hubungan timbal balik adalah Bejing yang memiliki reputasi baik yang ditunjukkan dengan ketepatan janjinya. Dari sisi kandidat, ketepatan janji yang sudah dibuat harus benar-benar dilaksanakan mengingat bahwa untuk pemilihan berikutnya tentu dia akan membutuhkan tenaga Bejing untuk memobilisasi massa. ketika janji itu tidak terlaksana maka kandidat akan kehilangan dukungan dari Bejing. Dengan kewibawaan yang dimiliki tentu Bejing memperhatikan dengan hatihati setiap perkataanya. Ketika Bejing ingkar janji kepada pemilih maka nama baiknya akan dipertaruhkan. Ketika nama baik dan kewibawaan itu hilang maka masyarakat tidak akan menghargai sosok Bejing tersebut. Dengan demikian, 
kandidat dan Bejing harus bekerjasama dengan baik dalam hal ini.

Kedua, Kandidat sebagai jalan Bejing untuk memenuhi kebutuhan masyarakat. untuk memelihara hubungan antara kandidat dan Bejing maka kandidat harus memperhatikan apa yang diminta oleh Bejing. Dalam persoalan pemenuhan kebutuhan pemilih, Bejing mengupayakan meminta bantuan kepada kandidat terkait apa yang sedang dibutuhkan oleh pemilih. ketika pemilih membutuhkan pos keamanan ataupun perbaikan jalan dan jembatan, maka peran Bejing mengabulkan hal tersebut dengan meminta kandidat merealisasikan kebutuhan masyarakat. dengan demikian keuntungan akan didapatkan oleh Bejing dan masyarakat. Bejing akan memiliki nama dan reputasi baik di mata masyarakat mengingat peranya yang baik dalam pemenuhan kebutuhan sekaligus masyarakat akan memberikan dukunganya kepada kandidat melalui perantara Bejing ketika pemilihan agar masyarakat mendapatkan lagi hal-hal yang mereka butuhkan.

Kerjasama dan hubungan timbal balik antara Bejing, pemilih dan kandidat dapat dijelaskan melalui bagan berikut :

Bagan 1

Hubungan Klientelisme

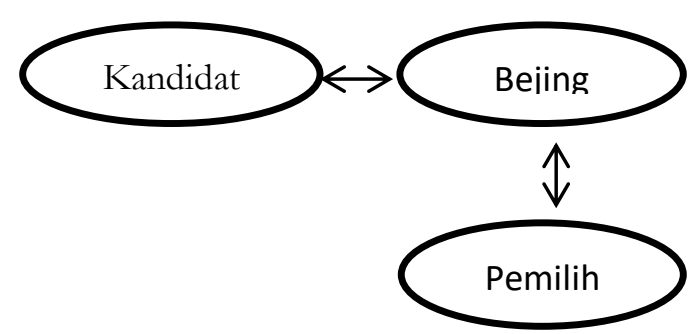

Bagan di atas menunjukkan bahwa klientelisme terjadi antara kandidat dengan Bejing sebagai makelar suara dan Bejing kepada pemilih. hal-hal penting yang dilakukan oleh pihak-pihak terkait dianatara adalah :

Pertama, Kandidat dengan Bejing ditunjukkan dengan timbal balik berupa materi yang akan diberikan kandidat ketika Bejing dalam memenangkan kontestasi. Kandidat juga menawarkan janji-janji kepada pemilih agar memudahkan Bejing bekerja mencari suara pemilih. janji janji tersebut masuk kedalam janji jangka panjang dan jangka pendek. Janji jangka panjang ditunjukkan dengan pembangunan sdangkan janji janka pendek ditunjukkan dengan pemberian materi berupa beras, uang, obat kesehatan dan lain-lain yang diperlukan oleh pemilih. janji tersebut dibuat oleh kandidat dan Bejing untuk menguntungkan satu sama lain. kandidat diuntungkan dengan kemenangan dimasa pemilihan yang akan datang sedangkan Bejing diuntungkan dengan nama baik di kalangan masyarakat karena menjadi perantara dalam memudahkan urusan masyarakat.

Kedua, timbal balik antara Bejing dan pemilih. hubungan ini dilatarbelakangi oleh kesepakatan bahwa Bejing akan memberikan hal-hal yang dibutuhkan oleh pemilih yang akan ditukar dengan loyalitas pemilih dalam pemilihan. Beberapa hal yang diberikan adalah materi berupa uang, makanan, bahan pokok dan lain sebagainya. Keamanan dimana Bejing menjamin keamanan pemilih baik dari keamanan diri dan juga keamanan harta benda dan ternak pemilih dari perampokan. Selain itu, Bejing juga menjanjikan pembangunan yang akan dilakukan oleh kandidat ketika memenangkan kontestasi. Hubungan timbal balik yang dilandaskan akan janjijanji yang menguntungkan akan menjamin suara pemilih dapat dikantongi dengan perhitungan yang baik. Tidak heran Bejing memiliki hitungan yang tidak pernah meleset akibat dari hubungan timbal balik yang terjalin baik dengan pemilih.

Dengan demikian, hubungan dari ketiga aktor dalam proses pemakelaran suara guna kemenangan pemilihan harus berjalan dengan baik. Ketika salah satu aktor tidak menjalankan peranya dengan baik maka hubungan makelar suara tidak akan berjalan sebagaimana mestinya.

\section{Jejaring Sosial dan Pendistribusian Barang}

Menjalankan peran sebagai makelar suara, Bejing memiliki struktur hierarki 
yang solid. Bejing membentuk struktur piramid yang terdiri dari Bejing yang bertindak di akar rumput untuk menjangkau orang-orang yang tinggal disekitarnya. Bejing juga memanfaatkan hubungan kekeluargaan dalam proses membangun jejaring sosial. Namun, ada Bejing tingkat atas yang menjadi pengendali jaringan.

Bejing yang berada di lapis bawah berdampingan dengan masyarakat dibagi tugas untuk mendistribusikan barang kepada pemilih sekaligus mengamankan suara pemilih agar tidak diambil oleh Bejing lawan. Sedangkan Bejing di tingkat atas akan memantau situasi dan sesekali turun tangan ketika ada permasalahan yang tidak bisa diselesaikan.

Jejaring sosial yang dibangun untuk penargetan pemilih dilakukan Bejing dengan memulai dengan perhitungan jaringan yang relevan. Pertama, Bejing melihat daftar-daftar nama pemilih dan memetakkanya sesuai dengan wilayahwilayah. Setelah itu Bejing memulai merekrut pemilih dalam batas keluarga. Keluarga besar menjadi jumlah pasti dalam mengantongsi suara untuk mendukung kandidat. setelah itu, Bejing mengelompokkan wilayah-wilayah mana saja yang akan ditargetkan menjadi pemilih. dalam hal pelaksanaanya, Bejing menyebar tim yang ada di setiap wilayah untuk mempengaruhi pemilih. dengan demikian setiap wilayah sudah pasti suara akan dipegang. Dengan demikian, suara yang diperoleh akan sesuai di setiap wilayah.

Bejing juga menjalankan kampanye dari rumah mereka dan kantor pemenangan. Mereka mempromosikan kandidat dari pintu ke pintu serta memasang poster, cat tembok dengan nama kandidat. Bejing dituntut menjadi juru kampanye yang efisien oleh kandidat baik dalam hal pendistribusian materi ataupun perekrutan pemilih yang akan melabuhkan suaranya kepada kandidat.
Gambar 1

Pos Pemenangan Calon Klebun

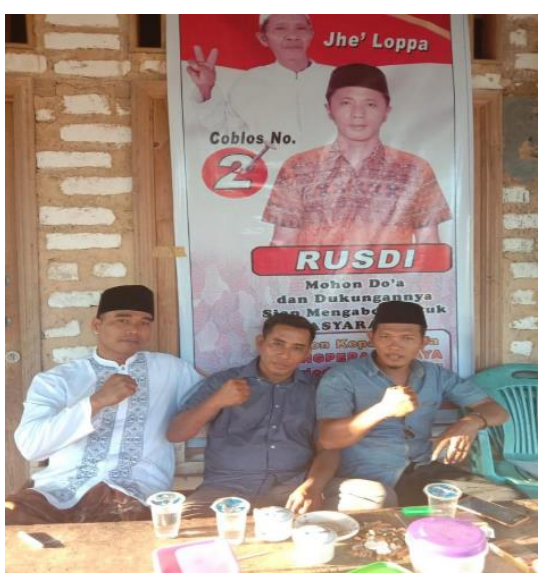

Selain bergerak dalam satu tim Bejing, mereka juga memanfaatkan suara para organisasi karang taruna atau organisasi lain yang ada di desa. Bejing dengan kemapanan finansial yang baik akan memberikan dana untuk para organisasi di desa maka dengan demikian suara mereka akan berlabuh kepada Bejing. Relasi yang dibentuk oleh Bejing kepada organisasiorganisasi inilah yang menjadi jalan Bejing mengantongi suara dengan pasti. Bejing juga akan mengevaluasi suara-suara baru yang muncul. Hal ini bisa menjadi bumerang bagi Bejing dengan alasan jebakan suara yang dilakukan oleh lawan.

\section{KESIMPULAN}

Sebagai makelar suara Bejing dengan power yang dimiliki mampu menjadi mekanisme yang diperhitungkan oleh kandidat untuk merekrut mereka mencari suara pemilih. kewibawaan, jagoanisme, dan mengenal preferensi pemilih dengan baik menjadi keahlian Bejing dalam menjalankan tugasnya sebagai makelar suara.

Hubungan Klientelisme yang terjadi antara Bejing dengan pemilih ditujukan sebagai kontrak pemilih untuk memberikan loyalitasnya dalam situasi pemungutan suara yang bersifat rahasia. Hubungan klientelisme terjadi dengan pertukaran uang dan barang serta hubungan jangka panjang berupa 
keamanan yang diberikan Bejing dari rawanya perampokan hilangnya harta benda dan ternak yang dimiliki oleh warga sebagai pemilih.

Bejing memiliki jejaring sosial yang multitak dimana dibentuk berdasarkan fungsinya sebagai pendistribusi materi serta menjaga suara pemilih.

Secara keseluruhan temuan penelitian ini memberikan bukti bahwa hubungan timbal balik, power yang dimiliki seorang makelar suara dan keseimbangan aktor baik kandidat, makelar suara dan pemilih harus berjalan beriringan untuk mencapai sebuah kemenangan.

Praktek broker yang memiliki otonomi penuh melebihi kandidat dengan alasan praktek ilegal yang terjadi menjadikan kewaspadaan kandidat dalam melakukan pengawasan terhadap kegiatan broker, maka penelitian lebih lanjut diperlukan.

\section{DAFTAR PUSTAKA}

Ainillah, S. R. (2016). Elite Politik Dalam Kontenstasi di Desa dengan menggunakan studi Peran Blater dalam Pilkades di desa Banjar, Galis, Bangkalan Madura. Jurnal Politik Muda, 5(3), 282-290. http://www.journal.unair.ac.id/dow nload-fullpapersjpm018f034c4e2full.pdf

Asmawati, Tawakkal, G. T. I., Muadi, S., \& Umanailo, M. C. B. (2020). Kemenangan Klebun: Ketahanan Bejingan dan Loyalitas Pemilih. Civic-Culture: Jurnal Ilmu Pendidikan PKn Dan Sosial Budaya, 4(2), 399407.

Asmawati, A., Tawakkal, T. I., \& Muadi, S. (2021). Religion, Political Contestation and Democracy: Kiai's Role as Vote Broker in Madurese Local Political Battle. Buletin AlTuras, 27(1), 37-54. https://doi.org/10.15408/bat.v27i1. 15650

Aspinall, E. (2014). WHEN BROKERS BETRAY: Clientelism, Social Networks, and Electoral Politics in
Indonesia. Critical Asian Studies, 46(4), $\quad 545-570$. https://doi.org/10.1080/14672715. 2014.960706

Hannan, A., Sosiologi, M., Ilmu, F., \& Politik, I. (2018). Agama, Kekerasan dan Kontestasi Politik Elektoral: Penggunaan Simbol Keagamaan Kiai dan Kekuasaan Blater Dalam Pertarungan Politik Lokal Madura. Jurnal Sosiologi Agama, 12(2), 187222.

Inan, B. Y. F. R. F., \& Chechter, L. A. S. (2012). Vote-Buying and Reciprocity. Econometrica, 80(2), 863881.

https://doi.org/10.3982/ecta9035

Kennedy, J. J. (2010). The Price of Democracy: Vote Buying and Village Elections in China. Asian Politics and Policy, 2(4), 617-631. https://doi.org/10.1111/j.19430787.2010.01215.x

Komito, L. (1992). Brokerage or friendship- Politics and Networks in Ireland. Economic and Social Review, 23(2), 129. https://search.proquest.com/docvie $\mathrm{w} / 1298057022$ ? accountid $=8312 \% 0$ Ahttp://rv2np5rk6k.search.serialsso lutions.com/?ctx_ver=Z39.882004\&ctx_enc $=$ info:ofi/enc:UTF8\&rfr_id=info:sid/ProQ\%3A\&rft_ val_fmt=info:ofi/fmt:kev:mtx:journ al\&rft.genre $=$ article $\&$ rft.jtitle $=\mathrm{EcO}$

Mahsun, M. (2020). Demokrasi Patronase dan Praktik Politik Uang: Pengalaman Pemilu Legislatif 2014 di Kota Pelembang, Sumatera Selatan. JPW Jurnal Politik Walisongo), 2(1), 13-26. https://doi.org/10.21580/jpw.2020. 2.1.1996

Mattlin, M. (2004). Nested pyramid structures: Political parties in Taiwanese elections. China Quarterly, 180 , 1031-1049. https://doi.org/10.1017/S03057410 04000736

Nichter, S., \& Palmer-Rubin, B. (2014). Clientelism, declared support, and Mexico's 2012 campaign. Mexico's Evolving Democracy: A Comparative Study of the 2012 Elections, 200-226. 
Ravanilla, N., Haim, D., \& Hicken, A. (2017). Brokers, Social Networks, Reciprocity, and Clientelism *. Aas, 2017.

Robinson, J. A., \& Verdier, T. (2013). The Political Economy of Clientelism*. Scandinavian Journal of Economics, 115(2), 260-291. https:// doi.org/10.1111/sjoe.12010

Rodrigo Zarazaga, S. J. (2014). Brokers Beyond Clientelism: A New Perspective Through the Argentine Case. Latin American Politics and Society, 56(3), 23-45. https://doi.org/10.1111/j.15482456.2014.00238.x

Wati, A., Muadi, S., \& Tawakkal, G. T. I. (2020). Hidup dalam Stigma: Kekerasan dan Religiuitas Bejingan. Al-Mada: Jurnal Agama, Sosial, Dan Budaya, 3(2), 109-202. https://doi.org/10.31538/almada.v 3i2.694

Review, K., \& Asia, S. (2009). Social origin dan Politik Kuasa Blater di Madura Abdur Rozaki Universitas Islam Negeri Sunan Kalijaga Yogyakarta Institute for Research and Empowerment Yogyakarta. 11(11), 1-12.

Tawakkal, G. T. I. (2017). Gapit: Jaringan Mobilisasi Suara di Pilkades. Politik Indonesia: Indonesian Political Science Review, 2(1), 30. https://doi.org/10.15294/jpi.v2i1.8 485

Towar, G., Tawakkal, I., Kistanto, N. H., Asy, H., Garner, A. D., Towar, G., Tawakkal, I., Kistanto, N. H., \& Asy, H. (2017). Asian Affairs: An American Review Why Brokers Don , $t$ Betray: Social Status and Brokerage Activity in Central Java Why Brokers Don' t Betray: Social Status. Asian Affairs: An American Review, 44(2), 52-68. https://doi.org/10.1080/00927678. 2017.1307641 